\title{
Towards Enhancing the Effectiveness of Classroom Designs for Natural Ventilation Comfort in Yola, Nigeria
}

\author{
Ogwu Ikechukwu1 ${ }^{*}$, Long Zhi Lin'1, Idowu Olusegun Moses², Okonkwo Moses ${ }^{3}$ \\ ${ }^{1}$ College of Civil Engineering and Mechanics, Xiangtan University, Xiangtan, China \\ ${ }^{2}$ Department of Architecture, Modibbo Adama University of Technology, Yola, Nigeia \\ ${ }^{3}$ Faculty of Environmental Science, Nnamdi Azikiwe University, Awka, Nigeria \\ Email: ${ }^{*}$ ogwu@smail.xtu.edu.cn
}

How to cite this paper: Ikechukwu, O., Lin, L.Z., Moses, O.I. and Moses, O. (2019) Towards Enhancing the Effectiveness of Classroom Designs for Natural Ventilation Comfort in Yola, Nigeria. Open Journal of Energy Efficiency, 8, 129-148. https://doi.org/10.4236/ojee.2019.83008

Received: August 20, 2019

Accepted: September 20, 2019

Published: September 23, 2019

Copyright $\odot 2019$ by author(s) and Scientific Research Publishing Inc. This work is licensed under the Creative Commons Attribution International License (CC BY 4.0).

http://creativecommons.org/licenses/by/4.0/

\begin{abstract}
Given the perennial incidence of thermal discomfort, health issues, as well as energy costs associated with naturally ventilated classrooms in Yola, the study aimed at enhancing the effectiveness of classroom designs for natural ventilation comfort by examining the effects of six architectural design variables-size and position of openings, form of buildings, orientation of buildings, site planning, topography, and physical features, on the ventilation coefficients of 61 classrooms selected from nine stratified clusters in Yola, Adamawa State, Nigeria. Data were analyzed using percentages, ratios, means as well as standard deviation, and then sorted in groups using tables. The study revealed that the form and orientation of the classroom-buildings, as well as topography, site planning and other physical features, have no significant effect on ventilation coefficient. In addition, a new mean ventilation coefficient was obtained in ten classrooms against an earlier claim that ventilation coefficient cannot exceed a fixed average regardless of the ratio of wall opening to floor area.
\end{abstract}

\section{Keywords}

Natural Ventilation, Ventilation Coefficient, Thermal Comfort, Passive Design, Energy Conservation

\section{Introduction}

Ventilation is primarily required for the human physiological need for oxygen from fresh air. It helps prevent the contamination of air and overheating of human body as well as the building structure. 
Defined as the supply of outside air indoor and the replacement of vitiated air, ventilation provides sufficient air from which oxygen for respiration by humans is extracted, while maintaining concentration of carbon dioxide within safe limits [1]. Ventilation could be achieved by natural or (and) artificial (mechanical) means. Natural ventilation can be induced by wind pressure, temperature difference (stack-effect), or humidity difference (cool-tower effect), wind towers, wind scoop, cool tubes, venturi tubes, solar chimney, air vents, etc., or a combination of any of these [2] [3] [4] [5] [6]. Natural ventilation can also be achieved by ordering of building forms and fenestration, orientation with respect to wind direction and the specification of appropriate materials for the building components or enclosure system [7]. While form deals with the size and shape of a building with its roof, fenestration involves the sizing and placement of openings like windows and doors on the enclosure system of the walls and roofs [8] [9]. The choice of (building) form, fenestration and materials are normally derived from a careful examination of relevant climatic information and data including air temperature, relative humidity, precipitation and wind.

With any given space, as a product of the architectural design process, ventilation is a fundamental requirement [8] [9] [10]. Indeed, effective and productive human activities require a conducive space [11] [12], which in turn depends partly, on adequate ventilation [13].

Architecture, as an activity that produces a classroom-design (and indeed any shelter in the built environment), has been described in different ways by different theorists at different times. Notwithstanding, a designed space must provide a decent and conducive environment for desired activities. Indeed, the fundamental function of a building is to protect its occupants from the harsh external environment. The architectural approach has always been prompted by the climate in the time past, resulting in Igloos for the Eskimos, round huts in Northern Nigeria, and rectangular forms in South-West Nigeria [10]. Even the cultural theory of form portrays buildings as the expression of the structural relationship between technological, social, symbolic and natural forces [14]. However, these forces have since been reinforced by economic, political and popular factors that arose from the global energy crisis of 1973 as well as climate change due to global warming, prompting the need for building, land, nature and energy conservation through practices that lower energy demand, including (but not limited to) designing spaces for natural ventilation.

\section{Background of Study}

Natural Ventilation is the passive change or movement of air within buildings [9]. It is an important aspect of design which has influenced form throughout history. Functional architectural designs for natural ventilation, requires micro-climatic analysis of buildings' location [3] [15] [16] [17] [18]. In fact, diverse architectural design-expressions are essentially, products of difference in climatic conditions [Gropius (1955) cited in [4]]. However, the design features of classrooms (in- 
cluding the location or site, orientation, form and size, fabric, and fenestration), in the hot dry climate of Yola appear generically same as those found in milder climatic zones of Nigeria.

Considering the perennial thermal discomfort, heat stress and other heat-related issues experienced in some naturally-ventilated building spaces in Yola, the extent to which classroom-designs are effective was attempted in this study. This, more so as said classrooms are operated on exclusive natural ventilation.

Similar ventilation studies done in other climatic regions have been documented, but first, it is important to analyze the climatic data of temperature, rainfall and relative humidity of Nigeria. Nigeria is grouped into four broad climatic zones: the hot dry, temperate dry, hot humid and warm humid zones [19]. In this classification, Yola, falls within the hot dry zone with mean daily maximum dry-bulb temperature during the dry season of not less than $35^{\circ} \mathrm{C}$; diurnal temperature range up to $20^{\circ} \mathrm{C}$; relative humidity not more than $40 \%$ and a mean yearly rainfall below $1000 \mathrm{~mm}$ (Upper Benue River Basin Development Authority Yola, 2009). Also, it is important to note that upper limit of comfortable temperature in naturally ventilated spaces in the tropics has been estimated as $31.5^{\circ} \mathrm{C}$, at wind speed of $1.0 \mathrm{~m} / \mathrm{s}$ [20]. Higher wind speeds may be desirable to maintain thermal comfort at higher temperatures, obtainable in a hot dry climate [21].

Now, in a study of thermal and visual comfort in ten selected primary school classrooms in the warm humid climate of Ile-Ife, Nigeria, a mathematical model was used, and it revealed that only 40 percent of the classrooms meet what was termed "good" ventilation criteria [22]. In a survey of 3,544 students and teachers in 29 naturally ventilated and air-conditioned classrooms in Hawaii, it was discovered that the temperature range of thermal comfort lies between $22.0^{\circ} \mathrm{C}$ and $29.5^{\circ} \mathrm{C}$ for occupants of naturally ventilated classrooms [23] reported by [20]. Studying the effects of building orientation, architectural features, window location, size and components, plan form, adjacent buildings, landscape elements and land forms on ventilation, it was reported that the (ventilation) coefficient of a space cannot exceed 0.4 [8]. A thermal comfort study of major parts of Nigeria reported the exceptional prevailing wind direction of North-West in Yola. This is against the North-East and South-West prevailing winds obtainable in other parts [10]. In the first International Development Agency Education Project initiated by the Nigerian Government to establish standards for the design and construction of school buildings throughout the federation, the complex nature of the climate of the northern zone brought about by contradictory requirements during the different seasons of the year was reported [17]. Another researcher [24] identified poor ventilation as a discrepancy in the compact layout system of buildings recommended for the hot dry zone.

Contrary to [8], the Centre Scientifique et Technique Du Batiment [25] reported in its study that ventilation coefficient (the ratio of wind speed at level indoor to the incoming wind speed at the same level outdoor) could be more or less than a reference value of 0.6 (referred to as global ventilation coefficient) depending on architectural features of building and space. 
Studying the effectiveness of window openings for natural ventilation in residential quarters in the warm humid climate of Ile-Ife, it was concluded that window openings were designed more for aesthetic appeals than for physiological needs [26]. In a case study of the School of Architecture at Lyon, France, designed for both natural and mechanical ventilation, the high level of discomfort experienced by the users of the multi-storey building was reported; openings at the roof level of the glazed atrium of the building were recommended to increase natural ventilation rate by stack-effect [27].

Most of the cited works above are in the hot humid climates and are microclimatically oriented. This is in agreement with [15] and [18] that thermal comfort through natural ventilation requires the analysis of a given location because a wide variation of climate conditions can occur as a result of local, natural and man-made features. Works done on thermal comfort indoors in the hot dry climate of Nigeria are mainly on temperature. Such works are even too generalized to be relevant to the various microclimatic conditions obtainable in different localities. This has created the situation whereby a prototype design of public and institutional buildings (including public primary schools) are repeated in micro-climatically different locations of the nation. Some of the buildings may not function efficiently in some locations [24]. To achieve efficient natural ventilation, there is a need to evaluate the functionality of buildings designed and constructed for natural ventilation in different localities, with a view to possibly review the designs [17]. Yola has been particularly known for its multiple prevailing wind directions and low wind speed [10]. There has not been any known attempt to study natural ventilation in buildings in the hot dry climate of Nigeria in general and Yola in particular. Among the consequences of lack of such study is the sustained ignorance of the design-causes of, and solution to inadequate natural ventilation. This dims the prospect of natural ventilation-enhancement of existing and proposed architectural spaces in the study area. The unpleasant experiences of thermal discomfort and heat stress and the attendant productivity-reduction continue unabated.

This work seeks to break a part of the unpleasant cycle; it evaluates, and aims to enhance the natural ventilation-functionality of classroom-designs in public primary schools in the hot dry climate of Yola.

\section{Methodology}

The Centre Scientifique et Technique du Batiment [25] proposed a method of evaluating Global Ventilation Coefficient $C_{\mathrm{G}}$, of wind-induced indoor air motion. The coefficient, defined as the ratio of the mean indoor air velocity, $V_{\mathrm{i}}$ at a height of 1.5 m to the outdoor air velocity $V_{\mathrm{o}}$, at the same height, is said to vary with the following:

1) Characteristics of the site;

2) Orientation of the building and of the wind;

3) Exterior characteristics of the building; 
4) Interior architecture and aerodynamics of the building.

The evaluation of four corresponding coefficients, $C_{\text {site }}, C_{\text {orientation }}, C_{\text {arch.exterior }}$, and $C_{\text {aero.inter }}$ was proposed by the method. The minimum of the four coefficients is taken as the global ventilation coefficient, $C_{\mathrm{G}}$ of a given space. That is:

$$
C_{\mathrm{G}}=\min \left(C_{\text {site }}, C_{\text {orientation }}, C_{\text {arch exterior }}, C_{\text {aero inter }}\right)
$$

With reference to the ventilation performance of a standard architectural model in a wind tunnel, each of these coefficients is evaluated using a specific, but detailed methodology. The ventilation performance of the standard architectural model is given as $C_{\mathrm{o}}=0.6$, and a required coefficient, $C_{\mathrm{x}}=f\left(C_{\mathrm{o}}\right)$.

The standard architectural model has a floor area of $30 \mathrm{~m}^{2}$ and a height between three and four meters with a ceiling slope of $10^{\circ}$ towards the wind direction. Inlet and outlet openings are about 30 percent of the respective windward and leeward walls, and the wind is incident perpendicular to inlet. The site is considered flat and obstruction-free [25].

\subsection{Evaluating the Coefficients}

The following steps are proposed to evaluate each of the four coefficients listed above [25].

\subsubsection{Evaluating the Characteristics of the Site Coefficient}

The value of the coefficient of the characteristics of site is derived from three other factors:

1) Site topography $\left(C_{\mathrm{TP}}\right)$, whether good or poor for airflow;

2) Site physical features $\left(C_{\mathrm{EP}}\right)$, like vegetation and other buildings;

3) Site planning $\left(C_{\mathrm{PM}}\right)$, to reflect the relative position of buildings on site.

There is a distinction between good and poor airflow sites. Good airflow sites and their proposed relative value or coefficients are:

1) Locations between two hills with good orientation to local wind, $C_{\mathrm{TP}}=1.1$ $C_{\mathrm{o}}$;

2) Locations on hill top with a building-roof sloping windward and roof slope higher than site slope, $C_{\mathrm{TP}}=1.2 C_{\mathrm{o}}$;

3) Locations on hill-top with a building-roof sloping parallel to site slope, $C_{\mathrm{TP}}$ $=\mathrm{C}_{\mathrm{o}}$;

4) Locations on hill-top with building-roof sloping windward and roof slope greater than site slope, $C_{\mathrm{TP}}=1.3 C_{\mathrm{o}}$.

Poor sites for airflow and their proposed relative value or coefficients are:

1) Windward locations at the lower level of a hill, $C_{\mathrm{TP}}=0.6 C_{\mathrm{o}}$;

2) Leeward locations at the level of a hill, $C_{\mathrm{TP}}=0.5 C_{\mathrm{o}}$;

3) Valleys deprived of local winds, $C_{\mathrm{TP}}=0.3 C_{\mathrm{o}}$;

4) Cliffs, $C_{\mathrm{TP}}=0.7 C_{\mathrm{o}}$.

To evaluate the coefficient of site physical features, the [25] assumes rural or low-density urban sites, with vegetation and other obstructions five to ten meters high at the windward side of buildings. It is proposed that: 
1) Buildings are sited at a distance not less than twelve times height of obstruction if such obstruction is parallel to wind direction;

2) Buildings are sited at a distance less than four times height of obstruction if such obstruction is perpendicular to wind direction;

3) If the two conditions above are fulfilled, then $C_{\mathrm{EP}}=C_{\mathrm{o}}$ and if otherwise, $C_{\mathrm{EP}}$ $\leq 0.5 C_{\mathrm{o}}$

4) For unobstructed buildings, $C_{\mathrm{EP}}=C_{\mathrm{o}}$.

To evaluate the coefficient of site planning, $C_{\mathrm{PM}}$ the method deals with two types of site planning:

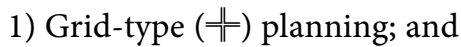

2) II-shape planning.

For grid-type planning, the value $C_{\mathrm{PM}}$ depends on the distances between rows of buildings, between buildings within a row, relative position of building's row from the first row, and angle between wind direction and normal axes to openings.

The value of $C_{\mathrm{PM}}$, according to the method, varies from $0.1 C_{\mathrm{o}}$ to $1.5 C_{\mathrm{o}}$, i.e. $0.1 C_{\mathrm{o}} \leq C_{\mathrm{PM}} \leq 1.5 C_{\mathrm{o}}$.

For II-type planning, [25] proposed the values of $C_{\mathrm{PM}}$ varying from $0.6 C_{\mathrm{o}}$ to $1.2 C_{\mathrm{o}}$.

When $C_{\mathrm{TP}}, C_{\mathrm{EP}}$ and $C_{\mathrm{PM}}$ have been evaluated, the coefficient, $C_{\mathrm{SITE}}$ is evaluated according to the following rules [25]:

1) If the conditions for the appropriate distance from neighboring obstacles are met, then $C_{\mathrm{SITE}}=C_{\mathrm{EP}}=C_{\mathrm{o}}$; If not and $C_{\mathrm{TP}}$ is higher or equal to $C_{\mathrm{o}}$ while the distance between neighboring buildings are appropriate then, $C_{\mathrm{SITE}}=\left(C_{\mathrm{PM}}+C_{\mathrm{TP}}\right) / 2$;

2) If the condition for appropriate distance from neighboring obstacles is met, and $C_{\mathrm{TP}}$ is lower than $C_{\mathrm{o}}$ then, $C_{\mathrm{SITE}}=C_{\mathrm{TP}}$;

3) If the building is located on hill-top with a windward orientated pitch roof of slope $20^{\circ}$ more than slope of hill, and the distance from neighboring building is appropriate while wind is incident normal to the opening, then $C_{\mathrm{SITE}}=$ $1.5 C_{\mathrm{o}}$;

4) If the building is located on hill-top with a wind-orientated pitch roof parallel to slope of hill, and the distances from neighboring buildings are appropriate while the wind is incident normal to opening, then $C_{\mathrm{SITE}}=1.3 C_{\mathrm{o}}$.

\subsubsection{Evaluating the Coefficient of the Orientation of the Building and the Wind, $C_{\text {orientation }}$}

The value of this coefficient according to [25] depends on the following parameters:

1) The angle between incident wind and normal axis to opening $\theta$,

2) The angle between incident wind and the orientation of the site plan $\Phi$;

3) The nature and characteristics of the site plan.

It is estimated that:

$C_{\text {orientation }}=C_{\mathrm{o}}$, if $\Phi=\theta \leq \pm 20^{\circ}$;

$C_{\text {orientation }}=0.75 C_{\mathrm{o}}$, if $\theta= \pm 45^{\circ}$; 
$C_{\text {orientation }}=0.5 C_{\mathrm{o}}$, if $\theta=90^{\circ}$.

\subsubsection{Evaluating the Coefficient of the Exterior Characteristics of the Building, $C_{\text {arch.exter }}$}

The value of this coefficient is dependent on five other factors:

1) The value and characteristics of the opening $C_{\mathrm{P}}$;

2) The architecture of the roof $C_{\mathrm{T}}$;

3) The existence of an open roof $C_{\mathrm{ET}}$;

4) The existence of concrete stilts $C_{\mathrm{PL}}$;

5) The presence of wind walls $C_{\mathrm{J}}$.

The value of $C_{\mathrm{p}}$ is estimated based on the porosity of the facades (porosity being the ratio of opening area to the area of bearing wall or facade) and the incident angle of wind to the opening.

If the incident wind is normal to windward opening and:

1) Porosity of the windward and leeward walls are 15 percent, then $C_{\mathrm{P}}=0.7 C_{\mathrm{o}}$;

2) Porosity of the windward and leeward walls are 30 percent, then $C_{\mathrm{P}}=C_{\mathrm{o}}$;

3) Porosity of the windward and leeward walls are 40 percent, then, $C_{\mathrm{P}}=1.2 C_{\mathrm{o}}$;

4) If there is a difference in porosity, then that of the leeward should be greater to improve airflow;

5) Effect of side opening is said to always be positive;

6) If there is no leeward opening, then side opening of equivalent porosity partly compensates.

The value of the effect of roof, $C_{\mathrm{T}}$, depends on whether building is on flat or sloping site. For buildings on flat site:

- $C_{\mathrm{T}}=0.6 C_{\mathrm{o}}$, for an extended flat roof;

- $C_{\mathrm{T}}=0.65 C_{\mathrm{o}}$, for a mono-pitch roof with highest part on windward façade;

- $C_{\mathrm{T}}=0.7 C_{\mathrm{o}}$, for a roof with four slopes (hipped roof);

- $C_{\mathrm{T}}=0.8 C_{\mathrm{o}}$ for a simple flat roof;

- $C_{\mathrm{T}}=0.9 C_{\mathrm{o}}$ for a double-pitch roof;

- $C_{\mathrm{T}}=C_{\mathrm{o}}$ for a mono-pitch roof with lowest path on the windward facade;

- $C_{\mathrm{T}}=1.1 C_{\mathrm{o}}$, for a building raised $1.5 \mathrm{~m}$ above ground, with a mono-pitch roof having lowest part on the windward facade.

For buildings on sloping site and the roof slopes opposite to the ground, the method proposes $C_{\mathrm{T}}=1.3 C_{\mathrm{o}}$.

The value of the effect of an open roof, $C_{\mathrm{ET}}$, is appreciable, provided there are two openings: one each on the windward and leeward façades and the total opening area per room is between two and three square meters. Two cases were examined by the method:

1) When the higher opening of the roof is on the windward façade, $C_{\mathrm{ET}}=1.15$ $C_{\mathrm{o}}$;

2) When the higher opening of the roof is on the leeward façade, $C_{\mathrm{ET}}=1.4 C_{\mathrm{o}}$.

The effect of a concrete stilt, $C_{\mathrm{PL}}$, is significant, according to the method, if a building is raised on concrete silt of height greater than one meter and there is unobstructed wind. In that case, $C_{\mathrm{PL}}=1.2 C_{\mathrm{o}}$. 
In the presence of a wing wall of minimum height and length of 2.5 and 2 meters respectively, its coefficient according to the method, $C_{\mathrm{J}}=1.1 C_{\mathrm{o}}$.

Having estimated $C_{\mathrm{P}}, C_{\mathrm{T}}, C_{\mathrm{ET}}$, and $C_{\mathrm{J}}$, the method proposes two building configurations and steps to evaluate the effect of their exterior characteristics, $C_{\text {arch.exter }}$. The two building configurations are:

1) Mono-zone buildings with windward or leeward openings; and

2) Multi-zone buildings with windward or leeward opening together with roof openings.

For mono-zone buildings with windward openings the following steps were proposed to evaluate $C_{\text {arch.exter: }}$ :

1) Windward and leeward openings should have porosities higher than 15 percent, and if there is no leeward opening, side opening should have porosity up to 20 percent. If these conditions are met and conditions " $2-3$ " below are not, then $C_{\text {arch.exter }}=C_{\mathrm{p}}$

2) In addition to condition " 1 " above, if there is a well designed roof opening, then $C_{\text {arch.exter }}=\left(C_{\mathrm{p}}+C_{\mathrm{ET}}\right) / 2$;

3) If the building is on concrete silts and has wing walls, then $C_{\text {arch.exter }}=\left(C_{\mathrm{p}}+\right.$ $\left.C_{\mathrm{PI}}+C_{\mathrm{T}}\right) / 3=\left(C_{\mathrm{P}}+C_{\mathrm{J}}=C_{\mathrm{T}}\right) / 3$;

4) If the windward and leeward openings have porosities of 30 percent and the building is on a slope, having roof slope opposite site slope, then $C_{\text {arch.exter }}=$ $1.3 C_{0}$.

For multi-zone buildings, with windward or leeward openings together with roof openings, the following steps were proposed to evaluate $C_{\text {arch.exter: }}$ :

1) If there is no wing walls and stilts, then $C_{\text {arch.exter }}=C_{\mathrm{ET}}$;

2) If the building has wing walls or stilts, then $C_{\text {arch.exter }}=\left(C_{\mathrm{ET}}+C_{\mathrm{J}}\right) / 2$,

$C_{\text {arch.exter }}=\left(C_{\mathrm{ET}}+C_{\mathrm{PI}}\right) / 2$.

\subsubsection{Evaluating the Effect of Interior Characteristics of Building, $C_{\text {aero.inter }}$}

Two building interior characteristics were recognized by the method as factors influencing airflow through the building:

1) The building internal partition $C_{\mathrm{c}}$; and

2) The building's furniture.

If the internal partition is parallel to airflow, then $C_{\mathrm{c}}=C_{\mathrm{o}}$. If the internal partition is perpendicular to airflow and has porosity more than 50 per cent, then $C_{\mathrm{c}}$ $=0.9 C_{0}$. If the internal partition is perpendicular to airflow and has porosity less than 20 per cent, then $C_{\mathrm{c}}=0.3 C_{\mathrm{o}}$ at the leeward zone. The windward zone is ventilated only if there are side openings with a porosity higher than 20 percent, in which case, $C_{\mathrm{c}}=0.8 C_{\mathrm{o}}$ at the windward zone.

The method did not propose steps to evaluate the effect of building furniture. Hence it was proposed that $C_{\text {aero.inter }}=C_{\mathrm{c}}$.

The concept of ventilation coefficient is relevant to the study in focus to the extent that it can be used to assess the ventilation status of architectural spaces in 
general. However it is not sufficient to evaluate the effectiveness of such spaces for natural ventilation in a given climatic context. For instance, an architectural space of ventilation of 0.5 may be considered adequate where the required wind speed for comfort is $0.6 \mathrm{~m} / \mathrm{s}$ and the available wind speed outside is above 1.2 $\mathrm{m} / \mathrm{s}$. The same space would be inadequate for natural ventilation where the required wind speed for comfort is $0.9 \mathrm{~m} / \mathrm{s}$ and the available wind speed outside is below $1.2 \mathrm{~m} / \mathrm{s}$.

\section{Discussions}

The effectiveness of classroom-designs for natural ventilation in the hot dry climate of Yola was investigated. 61 classrooms drawn from 9 primary schools (Table 1 below) were the subjects of the study. Classroom-design variables which affect ventilation coefficient (a natural ventilation parameter) have been identified to include: size and position of openings, form of buildings, orientation of buildings, site planning, topography and physical features. The effects of these variables on ventilation coefficients of the classrooms were examined and the findings presented below.

\subsection{Ventilation Coefficients}

The mean ventilation coefficient of all the studied classrooms was less than 0.5 (see Table 2). This suggests that less than half of the available (free) wind outside is admissible by the classroom designs. Openings are located at the workplane zones only and none at higher levels. Hence, the natural ventilation is only by wind, while the Stack, Bernoulli's and other effects are not exploited. In the study area, the mean external wind speed is below $1.0 \mathrm{~m} / \mathrm{s}$, suggesting low level of effectiveness of the classroom-design for natural ventilation. This tends to agree with the earlier study by [22] where only 40 percent of the classrooms were reportedly effective in terms of natural ventilation, in a warm-humid climate.

A comparison with the global ventilation, $C_{\mathrm{G}}(0.6)$ reported by [25] revealed some factors responsible for the low ventilation coefficients of the classroom-designs in the study area. Whereas the total opening area as percentage of floor area, and the ratio of outlet area to inlet area of the standard architectural model [25] were $40 \%$ and 1.3 respectively, the mean corresponding values are less than $20 \%$ and 1.0 for the studied classrooms. Even the three classrooms having ventilation coefficient of 0.7 (greater than $C_{\mathrm{G}}$ ) have total opening area ranging from $21.1 \%$ to $27.2 \%$ of floor area. Their ratio of outlet area to inlet area is however comparable to the standard architectural model, ranging from 1.2 to 1.5 . Some other incomparable factors may be responsible for the greater values of ventilation coefficient of the three classrooms. Attainment of a ventilation coefficient greater than 0.4 , as obtained by [25] and this finding (see Table 3), however contradicts the earlier work of [8] which reported a maximum attainable coefficient of 0.4 . 
Table 1. Identification numbers of studied classrooms.

\begin{tabular}{cc}
\hline Name of school & Identification number of studied classrooms \\
\hline Bekaji P/School & $\mathrm{B} / 1 \mathrm{~B} ; \mathrm{B} / 2 \mathrm{~A} ; \mathrm{B} / 3 \mathrm{~A} ; \mathrm{B} / 4 \mathrm{~A} ; \mathrm{B} / 5 \mathrm{C}$ \\
Capital P/School & $\mathrm{C} / 1 \mathrm{~A} ; \mathrm{C} / 2 \mathrm{Au} \mathrm{C} / 3 \mathrm{~B} ; \mathrm{C} / 4 \mathrm{~B} ; \mathrm{C} / 5 \mathrm{~A} ; \mathrm{C} / 6 \mathrm{~B} ; \mathrm{C} / 7 \mathrm{~A} ; \mathrm{C} / 8 \mathrm{~A}$ \\
Damare P/School & $\mathrm{D} / 1 \mathrm{~A} ; \mathrm{D} / 2 \mathrm{~B} ; \mathrm{D} / 3 \mathrm{~A} ; \mathrm{D} / 4 \mathrm{~A} ; \mathrm{D} / 5 \mathrm{~A} ; \mathrm{D} / 6 \mathrm{~A}$ \\
Karewa P/School & $\mathrm{K} / 1 \mathrm{~A} ; \mathrm{K} / 2 \mathrm{C} ; \mathrm{K} / 3 \mathrm{~A} ; \mathrm{K} / 4 \mathrm{C} ; \mathrm{K} / 5 \mathrm{C} ; \mathrm{K} / 6 \mathrm{~A} ; \mathrm{K} / 7 \mathrm{~B} ; \mathrm{K} / 8 \mathrm{~A}$ \\
Luggerre P/School & $\mathrm{L} / 1 \mathrm{~B} ; \mathrm{L} / 2 \mathrm{~A} ; \mathrm{L} / 3 \mathrm{~A} ; \mathrm{L} / 4 \mathrm{C} ; \mathrm{L} / 5 \mathrm{~A} ; \mathrm{L} / 6 \mathrm{~A} ; \mathrm{L} / 7 \mathrm{~A} ; \mathrm{L} / 8 \mathrm{~A}$ \\
Mustapha P/School & $\mathrm{M} / 1 \mathrm{~A} ; \mathrm{M} / 2 \mathrm{~B} ; \mathrm{M} / 3 \mathrm{~A} ; \mathrm{M} / 4 \mathrm{~A} ; \mathrm{M} / 5 \mathrm{~A} ; \mathrm{M} / 6 \mathrm{~A} ; \mathrm{M} / 7 \mathrm{~A} ; \mathrm{M} / 8 \mathrm{~A} ; \mathrm{M} / 9 \mathrm{~B}$ \\
Namtari P/School & $\mathrm{N} / 1 \mathrm{~A} ; \mathrm{N} / 2 \mathrm{E} ; \mathrm{N} / 3 \mathrm{~A} ; \mathrm{N} / 4 \mathrm{C} ; \mathrm{N} / 5 \mathrm{~B}$ \\
Toungo P/School & $\mathrm{T} / 1 \mathrm{Bg} ; \mathrm{T} / 1 \mathrm{Bu} ; \mathrm{T} / 3 \mathrm{~A} ; \mathrm{T} / 4 \mathrm{~A} ; \mathrm{T} / 5 \mathrm{~A} ; \mathrm{T} / 6 \mathrm{~A}$ \\
Yelwa P/School & $\mathrm{Y} / 1 \mathrm{~A} ; \mathrm{Y} / 2 \mathrm{~A} ; \mathrm{Y} / 3 ; \mathrm{Y} / \mathrm{Y} / 1 \mathrm{~A} ; \mathrm{Y} / 2 \mathrm{~A} ; \mathrm{Y} / 3 ; \mathrm{Y} / 4 \mathrm{C} ; \mathrm{Y} / 5 \mathrm{~B} ; \mathrm{Y} / 6 \mathrm{~A}$ \\
\hline
\end{tabular}

Table 2. Classrooms with ventilation coefficients less than 0.3.

\begin{tabular}{|c|c|c|c|c|c|c|}
\hline $\begin{array}{l}\text { Identification } \\
\text { number }\end{array}$ & $\begin{array}{l}\text { Form of } \\
\text { roof and } \\
\text { corridor }\end{array}$ & $\begin{array}{l}\text { Relative angle: } \\
\text { dominant wind } \\
\text { to inlet plane }\end{array}$ & $\begin{array}{c}\text { T.O.A } \\
\text { as \% of } \\
\text { floor area }\end{array}$ & $\begin{array}{l}\text { Outlet area/ } \\
\text { inlet area }\end{array}$ & $\begin{array}{l}\text { Window sill } \\
\text { height above } \\
\text { ground }(\mathrm{m})\end{array}$ & $\begin{array}{c}\text { Ventilation } \\
\text { coefficient } \\
\text { (V. C) }\end{array}$ \\
\hline $\mathrm{B} / 1 \mathrm{~B}$ & DWIC & NML & 12.0 & 0.5 & 0.9 & $<0.3$ \\
\hline $\mathrm{B} / 3 \mathrm{~A}$ & HWOC & NML & 12.2 & 0.5 & 1.0 & $<0.2$ \\
\hline $\mathrm{C} / 3 \mathrm{~B}$ & MWOC & PRL & 16.7 & 0.9 & 1.0 & $<0.3$ \\
\hline $\mathrm{D} / 3 \mathrm{~A}$ & DWIC & PRL & 16.0 & 1.0 & 1.3 & $<0.3$ \\
\hline $\mathrm{D} / 4 \mathrm{~A}$ & DWIC & NNP & 16.6 & 1.0 & 1.0 & $<0.3$ \\
\hline $\mathrm{K} / 1 \mathrm{~A}$ & DWOC & NML & 16.4 & 0.9 & 1.1 & $<0.3$ \\
\hline $\mathrm{K} / 3 \mathrm{~A}$ & MWIC & NML & 16.7 & 0.8 & 1.3 & $<0.2$ \\
\hline $\mathrm{K} / 4 \mathrm{C}$ & MWIC & PRL & 19.4 & 0.8 & 1.3 & $<0.2$ \\
\hline $\mathrm{K} / 6 \mathrm{~A}$ & DWOC & NNP & 15.4 & 0.9 & 1.0 & $<0.2$ \\
\hline $\mathrm{L} / 2 \mathrm{~A}$ & HWOC & NM & 14.3 & 0.3 & 1.4 & $<0.2$ \\
\hline $\mathrm{L} / 6 \mathrm{~A}$ & MWIC & PRL & 18.9 & 0.8 & 1.3 & $<0.2$ \\
\hline $\mathrm{L} / 7 \mathrm{~A}$ & HWOC & NNP & 15.8 & 1.1 & 1.2 & $<0.3$ \\
\hline $\mathrm{M} / 1 \mathrm{~A}$ & MWIC & PRL & 16.1 & 1.5 & 1.7 & $<0.2$ \\
\hline $\mathrm{M} / 2 \mathrm{~B}$ & NWIC & NNP & 15.4 & 0.8 & 1.7 & $<0.3$ \\
\hline $\mathrm{M} / 3 \mathrm{~A}$ & MWOC & NNP & 15.2 & 1.0 & 1.2 & $<0.3$ \\
\hline $\mathrm{M} / 4 \mathrm{~A}$ & DWIC & NNP & 22.9 & 0.9 & 1.2 & $<0.2$ \\
\hline $\mathrm{M} / 5 \mathrm{~A}$ & MWIC & NNP & 15.8 & 1.0 & 1.2 & $<0.3$ \\
\hline $\mathrm{M} / 6 \mathrm{~A}$ & HWOC & PRL & 16.0 & 0.9 & 1.0 & $<0.2$ \\
\hline $\mathrm{N} / 3 \mathrm{~A}$ & MWOC & NNP & 15.0 & 1.1 & 1.0 & $<0.3$ \\
\hline $\mathrm{T} / 1 \mathrm{Bg}$ & DWIC & NNP & 30.6 & 0.8 & 1.3 & $<0.3$ \\
\hline $\mathrm{T} / 5 \mathrm{~A}$ & MWOC & NNP & 13.5 & 1.9 & 0.8 & $<0.3$ \\
\hline $\mathrm{Y} / 2 \mathrm{~A}$ & MWIC & NNP & 16.1 & 0.7 & 0.6 & $<0.3$ \\
\hline $\mathrm{Y} / 4 \mathrm{C}$ & MWIC & NNP & 18.4 & 0.8 & 1.1 & $<0.2$ \\
\hline $\mathrm{Y} / 5 \mathrm{~B}$ & MWOC & NNP & 15.5 & 1.0 & 0.7 & $<0.2$ \\
\hline \multicolumn{3}{|c|}{ MEAN } & 16.7 & 0.9 & 1.1 & $<0.3$ \\
\hline \multicolumn{3}{|c|}{ STANDARD DEVIATION } & 3.64 & 0.31 & 0.26 & 0.05 \\
\hline
\end{tabular}


Table 3. Classrooms with ventilation coefficient 0.3 or below 0.5 .

\begin{tabular}{|c|c|c|c|c|c|c|}
\hline $\begin{array}{c}\text { Identification } \\
\text { number }\end{array}$ & $\begin{array}{l}\text { Form of } \\
\text { roof and } \\
\text { corridor }\end{array}$ & $\begin{array}{l}\text { Relative angle: } \\
\text { dominant wind } \\
\text { to inlet plane }\end{array}$ & $\begin{array}{l}\text { T.O.A as \% of } \\
\text { floor area }\end{array}$ & $\begin{array}{l}\text { Outlet area/ } \\
\text { inlet area }\end{array}$ & $\begin{array}{l}\text { Window sill } \\
\text { height above } \\
\text { ground }(\mathrm{m})\end{array}$ & $\begin{array}{c}\text { Ventilation } \\
\text { coefficient } \\
\text { (V.C) }\end{array}$ \\
\hline $\mathrm{B} / 4 \mathrm{~A}$ & DWOC & NNP & 16.2 & 0.9 & 1.0 & 0.3 \\
\hline $\mathrm{C} / 4 \mathrm{~B}$ & DWIC & PRL & 20.6 & 0.9 & 1.1 & $<0.4$ \\
\hline $\mathrm{C} / 5 \mathrm{~A}$ & HWOC & NNP & 15.9 & 1.3 & 0.8 & $<0.4$ \\
\hline $\mathrm{C} / 6 \mathrm{~B}$ & MWOC & PRL & 12.2 & 1.0 & 1.0 & $<0.4$ \\
\hline $\mathrm{C} / 7 \mathrm{~A}$ & MWIC & NNP & 18.9 & 1.3 & 1.0 & $<0.5$ \\
\hline $\mathrm{C} / 8 \mathrm{~A}$ & MWIC & NML & 17.3 & 1.3 & 0.9 & $<0.4$ \\
\hline $\mathrm{D} / 1 \mathrm{~A}$ & DWOC & PRL & 30.5 & 1.1 & 1.3 & $<0.5$ \\
\hline $\mathrm{D} / 5 \mathrm{~A}$ & MWIC & NNP & 19.5 & 1.0 & 1.2 & $<0.4$ \\
\hline $\mathrm{D} / 6 \mathrm{~A}$ & HWOC & NML & 13.3 & 0.7 & 1.1 & V5 \\
\hline $\mathrm{K} / 2 \mathrm{C}$ & MWOC & NML & 12.9 & 0.8 & 1.3 & 0.4 \\
\hline $\mathrm{K} / 5 \mathrm{C}$ & MWIC & PRL & 19.3 & 0.8 & 1.4 & 0.3 \\
\hline $\mathrm{K} / 7 \mathrm{~B}$ & DWOC & PRL & 16.3 & 1.0 & 1.1 & $<0.4$ \\
\hline $\mathrm{K} / 8 \mathrm{~A}$ & DWOC & NNP & 16.2 & 0.9 & 1.3 & $<0.4$ \\
\hline $\mathrm{L} / 1 \mathrm{~B}$ & DWOC & PRL & 16.9 & 1.0 & 1.3 & $<0.4$ \\
\hline $\mathrm{L} / 3 \mathrm{~A}$ & MWIC & NNP & 22.4 & 1.3 & 1.6 & $<0.5$ \\
\hline $\mathrm{L} / 4 \mathrm{C}$ & MWIC & PRL & 20.3 & 1.2 & 1.2 & $<0.4$ \\
\hline $\mathrm{L} / 5 \mathrm{~A}$ & HWOC & NNP & 13.8 & 1.7 & 1.1 & $<0.4$ \\
\hline $\mathrm{L} / 8 \mathrm{~A}$ & MWOC & NML & 10.3 & 1.0 & 1.2 & $<0.4$ \\
\hline $\mathrm{M} / 7 \mathrm{~A}$ & HWOC & NNP & 19.8 & 1.0 & 1.3 & $<0.4$ \\
\hline $\mathrm{M} / 9 \mathrm{~B}$ & HWOC & PRL & 17.9 & 1.1 & 1.3 & $<0.5$ \\
\hline $\mathrm{N} / 1 \mathrm{~A}$ & DWOC & NNP & 12.7 & 1.1 & 1.0 & $<0.4$ \\
\hline $\mathrm{N} / 4 \mathrm{C}$ & MWOC & NNP & 15.5 & 1.0 & 1.1 & $<0.5$ \\
\hline $\mathrm{N} / 5 \mathrm{~B}$ & MWOC & PRL & 13.5 & 0.6 & 1.3 & $<0.5$ \\
\hline $\mathrm{T} / 1 \mathrm{Bu}$ & DWIC & NNP & 30.4 & 0.8 & 5.2 & $<0.4$ \\
\hline $\mathrm{T} / 3 \mathrm{~A}$ & DWOC & NNP & 22.1 & 1.0 & 0.9 & $<0.4$ \\
\hline $\mathrm{T} / 4 \mathrm{~A}$ & MWIC & NNP & 16.1 & 1.0 & 1.1 & $<0.4$ \\
\hline $\mathrm{T} / 6 \mathrm{~A}$ & HWOC & NNP & 16.3 & 1.0 & 1.3 & $<0.4$ \\
\hline $\mathrm{Y} / 1 \mathrm{~A}$ & MWOC & NNP & 14.5 & 1.0 & 1.1 & $<0.4$ \\
\hline \multicolumn{3}{|c|}{ MEAN } & 17.6 & 1.0 & 1.3 & $<0.4$ \\
\hline \multicolumn{3}{|c|}{ STANDARD DEVIATION } & 4.73 & 0.22 & 0.78 & 0.05 \\
\hline
\end{tabular}

The orientation of the building does not appear significantly responsible for the general (95.2\%) low level of the ventilation coefficient of the classrooms. This is because only sixteen $(26.2 \%)$ of all the studied classrooms have window planes parallel to the dominant wind. However, among the nine classrooms having ventilation coefficient 0.5 or more, only one $(11.1 \%)$ has window planes parallel to wind. None of the three with ventilation coefficients of 0.7 have win- 
dow planes parallel to wind (see Table 4). There appears therefore to be a correlation between classroom ventilation coefficient and the angle of incidence of wind to window inlet plane. This agrees with [2] [4] and [8].

\subsection{Building Forms}

Classroom-building forms studied do not seem to have any significant effect on the ventilation coefficient of classrooms. The mean ventilation coefficient of the five form-groups range between $<0.3$ and $<0.5$ (Table 2 and Table 3). A paired comparison between the ventilation coefficients of buildings with mono-pitch roof and corridor (MWIC) with the corridor windward side (Mean V.C $<0.3$, $\mathrm{SD}=0.11$ ) and buildings with double pitch roof and corridor (DWIC) with the corridor on windward side (Mean V.C $<0.4, \mathrm{SD}=0.08$ ) using t-test (calculated $\mathrm{t}$-value $=2.0795$ and critical $\mathrm{t}$-value $=2.365$ at 0.05 confidence level) indicate in significant difference in the means. There is however a significant difference in the means of classroom-buildings with mono-pitch roof and corridor (MWIC) but different orientation to wind at 0.05 level of confidence. This suggests that building orientation play a more significant role than building form in natural ventilation.

In considering the slope of the roofs, the size of the corridors and the presence of wing walls, window hoods and shading devices, most of which the study did not cover, could be responsible for this outcome on building form. All the classrooms studied are rectangular in plan with mean "width to length ratio" of 2:3. Ceiling heights or classroom heights range from $2.6 \mathrm{~m}$ to $3.0 \mathrm{~m}$ with average value of $2.8 \mathrm{~m}$. The presence or absence of corridor along one or both sides of the length of classrooms is a major distinguishing feature. Corridor width ranges from $1.8 \mathrm{~m}$ to $2.4 \mathrm{~m}$.

Table 4. Classrooms with ventilation coefficient not below 0.5 .

\begin{tabular}{ccccccc}
\hline $\begin{array}{c}\text { Identification } \\
\text { number }\end{array}$ & $\begin{array}{c}\text { Form of } \\
\text { roof and } \\
\text { corridor }\end{array}$ & $\begin{array}{c}\text { Relative angle: } \\
\text { tominant wind } \\
\text { to inlet plane }\end{array}$ & $\begin{array}{c}\text { T.O.A as } \\
\text { of floor } \\
\text { area }\end{array}$ & $\begin{array}{c}\text { Outlet area/ } \\
\text { inlet area }\end{array}$ & $\begin{array}{c}\text { Window sill } \\
\text { height above } \\
\text { ground (m) }\end{array}$ & $\begin{array}{c}\text { Ventilation } \\
\text { coefficient } \\
\text { (V. C) }\end{array}$ \\
\hline B/2A & MWOC & NM & 16.3 & 0.7 & 1.1 & 0.5 \\
B/5C & MWIC & NNP & 21.1 & 1.3 & 1.2 & 0.7 \\
C/1A & MWIC & NM & 20.6 & 0.8 & 1.1 & 0.5 \\
C/2Au & DWIC & NM & 24.2 & 1.5 & 4.1 & 0.7 \\
D/2B & DWOC & PL & 28.3 & 2.4 & 1.2 & 0.5 \\
M/8A & DWIC & NNP & 17.2 & 1.0 & 1.0 & 0.5 \\
N/2E & MWIC & NM & 22.5 & 1.2 & 1.2 & 0.7 \\
Y/3 & HWOC & NNP & 17.3 & 0.8 & 0.9 & 0.5 \\
Y/6A & DWIC & NNP & 15.6 & 1.0 & 0.9 & 0.5 \\
& MEAN & & 20.0 & 1.2 & 0.14 & $<0.6$ \\
STANDARD DEVIATION & 3.88 & 0.47 & 0.92 & 0.09 \\
\hline
\end{tabular}


The forms of roof range from mono-pitch to double pitch and hipped roof, with roof slope from $15^{\circ}$ to $25^{\circ}$. Where the roof is mono-pitch, it slopes from the corridor side, bounded by a parapet wall of two or more meters in height, and drains to the opposite side. The effect of different roof and corridor forms on wind flow was not significantly manifested. Windows are casement with double leaves, with sill height $0.9 \mathrm{~m}$ above floor level. Windows can open $90^{\circ}$ to $180^{\circ}$ to opening plane. Doors are metallic and usually opens $180^{\circ}$ outwards. None of the classrooms have window or other openings $2.1 \mathrm{~m}$ above ground. There are no roof openings except by default in Damare (D/2B). Hence the possibility of ventilation by stack-effect is precluded.

\subsection{Orientation of Buildings}

The orientation of buildings with respect to the cardinal direction does not seem to affect their mean ventilation coefficients. Whereas 18 numbers $(29.5 \%)$ of the classroom-building are orientated $\mathrm{E} / \mathrm{W}$, with mean ventilation coefficient $<0.4$ $(\mathrm{SD}=0.15)$ and 43 numbers $(71.5 \%)$ are orientated N/S with mean ventilation coefficient $<0.4(\mathrm{SD}=0.1)$, there is no significant difference in their ventilation rate. In fact two $(66.7 \%)$ of the three classrooms with ventilation coefficient $=0.7$, have E/W orientation. Whereas only three (7.0\%) of all the classrooms orientated $\mathrm{N} / \mathrm{S}$ have ventilation coefficient 0.5 or more, six (33.3\%) of those orientated $\mathrm{E} / \mathrm{W}$ have ventilation coefficient 0.5 or more. Hence, the more adopted N/S orientation recommended to minimize solar radiation does not seem to have more positive impact on natural ventilation than the $\mathrm{E} / \mathrm{W}$ orientation.

Even in terms of orientation to wind, there seem to be no noticeable effect of wind direction on mean ventilation coefficients. A paired comparison of the mean ventilation coefficient of building with window plane normal (NML) to dominant wind and those parallel (PRL) to dominant wind indicate no significant difference in the mean values (calculated $t=0.9578$ and $t$, critical $=2.156$ ). The reason for this may not be far-fetched. The effect of other variables may be at play. For instance a closer look shows that four (38.5\%) of all the classrooms with wind normal (NML) to window planes have ventilation coefficients 0.5 or above, whereas only one (6.25\%) of the classrooms with dominant wind parallel (PRL) have ventilation coefficient 0.5 , and that is an exception.

The building $\mathrm{D} / 2 \mathrm{~B}$ has an open roof. [25] had earlier reported the positive effect of open roof on natural ventilation. Five (15.6\%) of the classrooms with window planes neither normal nor parallel (NNP) to dominant wind have ventilation coefficients 0.5 or above. These ratio seem to suggest that ventilation coefficient increases with wind direction from parallel (PRL) (6.25\%) to neither normal nor parallel (NNP) (15.6\%) and normal (NML) (38.5\%) to window planes. This again agrees with earlier study by [2] [4] and [8]. The incapacity of the wind meter to measure wind speed below $0.3 \mathrm{~m} / \mathrm{s}$ may partly contribute to the apparently non-conforming results.

Orientation of buildings in relation to cardinal direction varies between North- 
South and East-West. This has some effect on the likelihood of opening windows. Windows are not likely to be opened when it admits direct solar radiation into classrooms; when building is oriented East-West. Classrooms B/IB and $\mathrm{K} / 3 \mathrm{~A}$ are examples in this category. However, orientation of building does not appear to affect wind flow because wind directions vary with location and time. Classrooms $\mathrm{C} / 3 \mathrm{~B}, \mathrm{C} / 6 \mathrm{~B}, \mathrm{D} / 3 \mathrm{~A}, \mathrm{~K} / 4 \mathrm{C}, \mathrm{M} / 1 \mathrm{~A}$, and $\mathrm{M} / 9 \mathrm{~B}$ are all oriented North-South, but wind direction observed was parallel to window plane. Classrooms $\mathrm{B} / 3 \mathrm{~A}, \mathrm{D} / 6 \mathrm{~A}$, $\mathrm{K} / 1 \mathrm{~A}, \mathrm{AND} \mathrm{N} / 2 \mathrm{E}$ have same North-South orientation and wind direction normal (NML) to window plane. On the other hand, classrooms $\mathrm{B} / 1 \mathrm{~B}, \mathrm{~B} / 2 \mathrm{~A}, \mathrm{C} / 1 \mathrm{~A}$, $\mathrm{C} / 2 \mathrm{~A}, \mathrm{~K} / 2 \mathrm{C}, \mathrm{K} / 3 \mathrm{~A}$ and $\mathrm{L} / 2 \mathrm{~A}$ are oriented East-West but experienced wind flow normal to window plane. Classroom D/1A has East-West orientation but wind flow parallel to window plane. Hence, when blows normal to window plane, wind flow is highly enhanced. When the wind is parallel to window plane, there is poor wind flow into the classrooms. The two cases occur irrespective of the building orientation.

There is only one classroom with wing wall that is more than one meter in width, classroom $\mathrm{C} / 4 \mathrm{~B}$. This may account for a relatively fair airflow to the classroom despite the fact that the wind flow outside was parallel to window plane. The presence of open roof by default in classroom $\mathrm{D} / 2 \mathrm{~B}$ may have contributed significantly to its wind flow despite the unfavorable (parallel to window plane) wind direction.

\subsection{Size and Position of Openings}

The size of openings seems to significantly affect the ventilation coefficient of classroom when there is appreciable variation in opening size and positions. This reinforces the report of [28]. For instance, there is a significant difference (at 0.05 confidence level) between the mean ventilation coefficient of classrooms with total opening area below 15 percent and those 20 percent or more (calculated $\mathrm{t}$-value $=2.243$ and critical $\mathrm{t}$-value $=2.170$ ). A paired comparison between classrooms with total opening area below 15 percent of floor area and those 15 or less than 20 percent reveal a contrary trend. The mean ventilation coefficient of the former is slightly higher than that of the latter.

A number of factors may be responsible. A noticeable factor is the orientation of window planes to dominant wind direction. Whereas there are only two (16.7\%) of the classroom in the former group with window planes parallel to wind, ten $(27.8 \%)$ of those in the latter group (TOA $15 \%$ or $<20 \%$ of floor area) have window plane parallel to wind.

The position of opening in terms of distribution on windward (inlet) and leeward (outlet) facades seem to have a significant effect on the ventilation coefficient of the classrooms. All the openings are located at work-plane zones, on opposite walls and none on adjacent walls. This is partly because the adjacent walls are either partitions between classroom or bearing blackboards, and other teaching aids. The mean ventilation coefficient of the classroom with ratio of outlet area to inlet area less than one is significantly (at 0.05 confidence level) 
lower than that of classroom with same ratio being one or more (Calculated $\mathrm{t}=$ 3.334 and critical $=2.045$ ). There is also a significant difference in the mean ratio of outlet area to inlet area in the two groups (that of former is $0.7 \mathrm{SD}=0.25$, and of latter 1.2, $\mathrm{SD}=0.30$ ). This outcome is in line with the earlier work of [8].

The position of opening in terms of window sill height above ground does not appear to have any significant effect on the ventilation coefficients of the classrooms even when there is a significant difference in height. For instance the difference in the mean window sill height above ground not more or less than two meters $(0.92 \mathrm{~m}, \mathrm{SD}=0.11)$ and those more than one or less than two meters $(1.25 \mathrm{~m}, \mathrm{SD}=0.15)$ is significant at 0.05 confidence (calculated $\mathrm{t}=9.599$ and critical $t=2.062$ ), but there is no significant difference in their mean ventilation coefficient (calculated $t=1.551$ and critical $t=2.062$ ). Even the paired comparison between classrooms with window sill height above two meters (mean height $4.7 \mathrm{~m}, \mathrm{SD}=6.55$ ) and those less than two meters (mean height $1.25 \mathrm{~m}, \mathrm{SD}=$ 0.15 ), there is no significant difference (at 0.05 confidence level) between their mean ventilation coefficients (calculated $t=1.573$ and critical $t$-value $=7.318$ ). There are two classrooms on the upper floors of storey buildings; hence their window sill height relative to the floor may not be significantly different from those of classrooms on ground floor.

\subsection{Regression Analysis}

A linear regression of ventilation coefficient against the other variables, using the SPS5 17.0, yielded a coefficient of determination, $R^{2}=0.18$. This value is considered too low to produce a fairly reliable predictive linear equation. Because the study is primarily an evaluation and not a predictive or exploratory research, some other uncontrolled factors such as the inability of the anemometer to measure speed below $0.3 \mathrm{~m} / \mathrm{s}$ and the unstable and uncontrollable wind directions may have significantly reduced the coefficient of determination.

\subsection{Effectiveness of Classroom-Designs}

The maximum value of the mean external wind speed in Jimeta is $1.22 \mathrm{~m} / \mathrm{s}$ (SD $=0.26)$ while that of Yola is $1.1 \mathrm{~m} / \mathrm{s}(\mathrm{SD}=0.27)$ both occurring in the month of April. There is no significant difference between the two means (at 0.05 confidence level calculated value of $t=1.222$ and critical value of $t=2.101$ ). Hence the values from the different sources (meteorological stations) do significantly agree and could be relied upon. The mean value of the instantaneous wind speeds observed in January and March (2009) respectively at all the schools are $0.80 \mathrm{~m} / \mathrm{s}(\mathrm{SD}=0.43)$ and $1.04 \mathrm{~m} / \mathrm{s}(\mathrm{SD}=0.28)$. These values also significantly agree with the corresponding values of $0.82 \mathrm{~m} / \mathrm{s}(\mathrm{SD}=0.27)$ and $0.97 \mathrm{~m} / \mathrm{s}(\mathrm{SD}=$ $0.22)$ in Jimeta (meteorological station) and $0.71 \mathrm{~m} / \mathrm{s}(\mathrm{SD}=0.23)$ and $0.94 \mathrm{~m} / \mathrm{s}$ $(\mathrm{SD}=0.22)$ in Yola (meteorological station). A mean value of $1.0 \mathrm{~m} / \mathrm{s}$ is considered reasonable as reference available external wind speed for natural ventilation design purpose in the study area and climate.

The desired wind speed for thermal comfort (based on the effective tempera- 
ture of $26^{\circ} \mathrm{C}$ ) when the dry bulb temperature is $34^{\circ} \mathrm{C}$ and relative humidity of $45 \%$ is $1.50 \mathrm{~m} / \mathrm{s}$. This seems to agree with [13] and [20] to the effect that wind speed above $1.5 \mathrm{~m} / \mathrm{s}$ may be required for thermal comfort at temperatures above $31.5^{\circ} \mathrm{C}$.

A desired indoor wind speed of $1.5 \mathrm{~m} / \mathrm{s}$ when the outdoor wind speed is 1.0 $\mathrm{m} / \mathrm{s}$ calls for a classroom-design with ventilation coefficient of 1.5 (required indoor wind speed divided by available external wind speed). This may be referred to as the critical ventilation coefficient for an architectural space. It is expected to vary with climatic conditions and regions. For Yola, at temperature of $35^{\circ} \mathrm{C}$ and relative humidity of $45 \%$ considered as the most unbearably hot climate condition, the critical ventilation coefficient is 1.5 . If the required ventilation coefficient is 1.5 and the maximum observed ventilation coefficient is 0.7 , then none of the classroom-designs studied in the study area meet the required level of effectiveness in terms of natural ventilation. If the effectiveness of classroom-design for natural ventilation is expressed in terms of natural ventilation obtainable as percentage of that required for thermal comfort, then three (4.9\%) of the classrooms having ventilation coefficient of $0.7 \%$ are $46.7 \%$ effective, while only nine $(14.7 \%)$ of the classrooms having ventilation coefficient of 0.5 or more are $33.3 \%$ effective in the study area and climate. A substantial 52 classrooms (85.3\%) fall below 33.3\% level of effectiveness. The average level of effectiveness of the classroom-designs studied for natural ventilation in the hot dry climate of Yola is $29.3 \%$.

\subsection{Effect of Site Differences}

There is no significant difference in the mean ventilation coefficient of the studied classrooms and schools. This shows that the effect of site topography, planning, adjacent buildings, fences, and other site features is not significantly different in the mean from site to site. It does not suggest that these site conditions do not affect the ventilation coefficient of individual classrooms. On the contrary, it could be observed that all the classrooms where definite value of ventilation coefficient were obtained $(\mathrm{B} / 2 \mathrm{~A}, \mathrm{~B} / 5 \mathrm{C} / \mathrm{C} / 1 \mathrm{~A}, \mathrm{C} / 2 \mathrm{Au}, \mathrm{D} / 2 \mathrm{~B}, \mathrm{~K} / 2 \mathrm{C}, \mathrm{K} / 5 \mathrm{C}$, $\mathrm{M} / 8 \mathrm{~A}, \mathrm{~N} / 2 \mathrm{E}$, and $\mathrm{Y} / 6 \mathrm{~A}$ ) have virtually no discernable obstruction to wind flow on their windward sides, despite variation in topography, planning and physical features.

\subsection{Contradictory Claims}

That the definite mean ventilation coefficient of ten classroom (0.54) is significantly higher than maximum obtainable value (0.4) reported by [8] even when mean value of total opening area ( $19.8 \%$ of floor area) is significantly lower than $25 \%$ is a sharp contradiction. The contradiction may not be attributable to difference in methodology. The study by [25] using simulated architectural model in a wind tunnel as did [8] produced a reference ventilation coefficient of 0.6. Values higher or lower than the reference ventilation coefficient are obtainable 
depending on site conditions, orientation of building in relation to wind, exterior characteristics, as well as the interior architecture and aerodynamics of the building. The focal theory emerging from empirical data of live buildings seem to strengthen the background theory of [25] that ventilation could be more than 0.4 and weaken the contrary theory by [8].

\subsection{Conclusion from the Findings}

The ventilation studies done by [22] on classrooms in Ile-Ife, and [23] in Hawaii on residential and institutional buildings in Hong Kong are typical micro-climatic oriented works in different locations and climates. These are in consonance with [15] [17] and [18] to the effect that a functional design for natural ventilation requires micro-climatic analysis of a location. There has not been any known attempt to study natural ventilation in buildings in a hot dry climate of Nigeria in general and Yola in particular. This work evaluated the functionality of classroom-designs for natural ventilation in public primary schools in the hot dry climate of Yola. There was also the need to establish the applicability and limitations of existing generalized theories on natural ventilation to the peculiar climatic context of the study area. There appeared to be no contextual benchmark for assessing effectiveness of architectural designs in terms of natural ventilation. Such a benchmark, if it existed, had not been established for the study area. This study has been able to fill some of the gaps highlighted.

The ventilation coefficients of the studied classrooms was discovered to range from values less than 0.2 to values as high as 0.7 with mean value less than 0.5 . These values may not ordinarily be considered too low or too high except considered in the light of the climatic context of the study area.

It was also discovered that:

1) The forms of the classroom-buildings have no significant effect on their mean ventilation coefficients. This is contrary to earlier claims by [2] and [8];

2) The orientation of the classroom-buildings in relation to cardinal directions was found not to significantly affect the ventilation coefficient of the classrooms. It was however revealed that the orientation of the classroom-buildings in relation to wind directions significantly affected the ventilation coefficient of classrooms. This agrees with earlier claims by [2] [8] and [25];

3) The other variables that were found to have significant effects on ventilation coefficient of the classrooms are: size of openings expressed in terms of total opening area as percentage of floor area, position of openings expressed as ratio of outlet area to inlet area (this also reinforces earlier claims by [2] [8] and [25]);

4) "Critical" ventilation coefficient was propounded as a contextual bench mark for assessing the effectiveness of architectural spaces. A "critical" ventilation coefficient of 1.5 was established for the study area, the basis upon which the classrooms studied were found to be $13 \%$ to $47 \%$ effective in terms of natural ventilation;

5) Ventilation coefficient of 0.54 , which is significantly higher than 0.4 , was 
obtained in the study area. This is contrary to an earlier claim by [8];

6) Differences in site conditions (topography, planning and physical features) in the study area do not have any significant effect on ventilation coefficients of the classrooms (this is at variance with [25]).

\section{Summary and Recommendations}

The mean ventilation coefficient of the classrooms in the study area is below 0.5 suggesting that the available wind is not maximally utilized for natural ventilation inside the classrooms. The effect that the classroom-building forms have on this ventilation rate could not be determined from the study. Even the orientation of the buildings with respect to cardinal directions does not seem to affect the mean ventilation rate of classrooms. The size of openings, however, significantly affects the ventilation rate in the classrooms. A "critical" ventilation coefficient of 1.5 has been established for architectural spaces in the study area. Given the low level of the available external wind and the desired mean ventilation coefficient, the classroom-designs are inadequate for natural ventilation required for comfort in the study area and climate. The average level of effectiveness of the classroom-designs studied for natural ventilation in the hot dry climate of Yola is $29.3 \%$.

The claim by [8] that ventilation coefficient cannot exceed 0.4 has been refuted by the study, given that a mean value of 0.54 was obtained in some classrooms. The effect of differences in site conditions in the study area is not significant, contrary to [25].

To improve the ventilation coefficient of the classrooms in the study area, the following retrofitting action for existing classrooms and guidelines for future designs are recommended:

- Sizes of classroom openings should be increased to a minimum of 30 percent of the floor area;

- Shading devices should be provided for openings exposed to direct solar radiation;

- High-level window openings should be provided to generate ventilation by both wind and stack effect;

- Trees should be planted around classrooms to reduce the negative effect of solar radiation on comfort, and redirect by-passing wind.

Guidelines recommended for future classroom-designs are:

1) Porosity of walls should be at least 30 percent of wall area;

2) Openings should be of equal size on opposite walls to optimize the effect of out let-inlet-ratio on ventilation;

3) Windows should be alternately arranged on opposite walls rather than direct opposite arrangement;

4) Roof openings and other ventilation including techniques should be incorporated into designs to generate ventilation by both wind and stack-effect;

5) Multi-storey buildings should be encouraged to reduce overcrowding of buildings at ground level and exploit more wind at higher levels; 
6) Classroom-buildings should be orientated North-South to minimize solar radiation;

7) Classroom-buildings should have corridors and shading devices to encourage opening all windows;

8) Roof slope should be at least $30^{\circ}$;

9) Rectangular plan form of length-to-width ratio of 1.7:1 should be adopted;

10) Plan forms and other elements that can catch wind from all directions and redirect by-passing wind into classrooms should be adopted.

\section{Acknowledgements}

Ogwu Ikechukwu thanks Dr. Idowu Olusegun Moses for his immense contribution to the work.

\section{Conflicts of Interest}

The authors declare no conflicts of interest regarding the publication of this paper.

\section{References}

[1] Bayoumi, M. (2018) Improving Natural Ventilation Conditions on Semi-Outdoor and Indoor Levels in Warm-Humid Climates. Buildings, 8, 75.

http://www.mdpi.com/journal/buildings https://pdfs.semanticscholar.org/b7ba/eabf19b63c9fd9cbc5f450d30fa2fc2116e8.pdf

[2] Boutet, T.S. (1987) Controlling Air Movement: A Manual for Architects and Builders. McGraw Hill Book Company, New York.

[3] Walker, A. (2003) Natural Ventilation Design Guidance. National Renewable Energy Laboratory, Golden, 3-4.

[4] Lechner, N. (1991) Heating, Cooling, Lighting: Design Methods for Architects. John Wiley \& Sons, New York.

[5] Santamouris, M. (1998) Natural Ventilation in Buildings: A Design Handbook. James \& James (Science Publishers) Ltd., London.

[6] Ismail, M. and Abdul Rahman, A.M. (2012) Stack Ventilation Strategies in Architectural Context: A Brief Review of Historical Development, Current Trends and Future Possibilities. International Journal of Research and Reviews in Applied Sciences, 11, 291-301. https://www.arpapress.com/Volumes/Vol11Issue2/IJRRAS_11_2_14.pdf

[7] Von Meiss, P. (1991) Elements of Architecture: From Form to Place. Chapman and Hall, Lausanne.

[8] Chand, I. (1976) Design Aid for Natural Ventilation in Buildings. In: Functional Aspect of Building Design: Lecture Program, Central Building Research Institute, Roorkee, 24-36.

[9] Burberry, P. (1979) Environment and Services. BT Baisford Limited, London.

[10] Ojosu, J.O. (1988) Climatic Data and Solar Energy Resources as Design Tools for Modeling Low Energy and Climate-Responsive Architecture in Nigeria. In: Proceedings of the National Seminar on Architecture, Climate and the Environment, Nigerian Building \& Road Research Institute (NBRRI), Lagos, 197-213.

[11] Olgyay, V. (1963) Design with Climate: Bioclimatic Approach to Architectural Regionalism. Princeton University Press, Princeton. 
[12] Akinniyi, E.O. (2006) Improving Minimum Standards for Educational Buildings in Technical Colleges in Adamawa State. An M. Tech Dissertation Submitted to the Department of Technology Education, Federal University of Technology, Yola.

[13] Fanger, P.O. (1973) Thermal Comfort: Analysis and Applications in Environmental Engineering. McGraw-Hill Book Company, New York.

[14] Markus, T.A. and Morris, E.N. (1980) Buildings, Climate and Energy. Pitman Publishing Limited, London.

[15] Watson, D. (1982) Bioclimatic Design Research Advances in Solar Energy. Plenum Press, New York.

[16] Fullerton, R.L. (1983) Building Construction in Warm Climates 2. Oxford University Press, Oxford.

[17] Godwin, J. (1988) Natural Conditioning and Thermal Design for Building for Comfort in Different Climate Zones. In: Seminar on Architecture, Climate and Environments, National Nigeria Building \& Road Research Institute (NBRRI), Lagos, 43-51.

[18] Szokolay, S.V. (1990) Design and Research Issues: Passive Control in the Tropics. Proceedings. First World Renewable Energy Congress, Readings, 2337-2344.

[19] Komolafe, L.K. (1988) Influence of Climate on Building Design and Thermal Performance Assessment of Some Construction Materials. In: Omange, G.N., Ed., Ten Years of Building and Road Research Commemorative Publication, Nigerian Building \& Road Research Institute (NBRRI), Lagos, 95-108.

[20] Tantasavasdi, C., Srebric, J. and Chen, Q. (2001) Natural Ventilation Design for Houses in Thailand. Energy and Buildings, 33, 815-824. https://doi.org/10.1016/S0378-7788(01)00073-1

[21] IHVE (1970) A Guide Book. Institution of Heating and Ventilation Engineers, London.

[22] Ajibola, K. (1994) An Evaluation of Thermal and Visual Comfort in Classrooms in a Warm Humid Climate: A Case Study of Ile-Ife, Nigeria. Proceedings of International Congress on Energy and Environments, Croatia, 26-28 October 1994, Vol. 1, 269-276.

[23] Kwok, A.G. (1998) Thermal Comfort in Tropical Classrooms. Ashrae Transaction, 104, $16 \mathrm{p}$.

[24] Izomoh, S.O. (1988) Thermal Design of Buildings for Comfort in Different Nigerian Climatic Zones. In: Proceedings on National Seminar on Architecture, Climate and Environment, Nigerian Building \& Road Research Institute (NBRRI), Lagos, 67-78.

[25] CSTB (1992) Centre Scientifique et Technique Du Batiment. Guide sur Ia climatisation naturalle de l'habitat en climat tropical humide-Methodologie de prise en comple des parameters climatiques dans l'habitat et conseils practiques. Practiques. Tome 1, Paris. (In French)

[26] Ajibola, K. (1997) Ventilation of Spaces in a Warm Humid Climate: Case Study of Some Housing Types. Renewable Energy, 10, 61-70. https://doi.org/10.1016/0960-1481(95)00128-X

[27] Maldonado, E. and Alexandre, J.L. (1998) Naturally Ventilated Buildings-Single Family Residence in Gaia. In: Allard, F., Ed., Natural Ventilation in Buildings. $A$ Design Handbook, James and James (Science Publishers) Ltd., London, 253-266.

[28] Liman, K. and Abadie, M. (1998) Naturally Ventilated Buildings-Porte Oceane Residence. In: Allard, F., Ed., Natural Ventilation in Buildings, James and James (Science Publishers) Ltd., London, 307-315. 